\title{
Measurement of DNA antibodies by double antibody precipitation
}

\author{
D. N. GLASS, JANET CAFFIN, R. N. MAINI, AND J. T. SCOTT \\ Clinical Division, Kennedy Institute of Rheumatology and Charing Cross Hospital
}

Antibodies to nuclear constituents particularly to native deoxyribonucleic acid (DNA) have been detected in the serum and tissues of patients with systemic lupus erythematosus (SLE) and may be involved in the pathogenesis of the disease when deposited as immune complexes (Tan, Schur, Carr, and Kunkel, 1966). The methods used for the detection in serum included immunoprecipitation (Seligmann, 1957) and complement fixation (Ceppellini, Polli, and Celada, 1957). More recently an isotope-labelled DNA-binding technique (Wold, Young, Tan, and Farr, 1968) has provided an assay which is of considerably increased sensitivity and has become a widely used method of demonstrating DNA antibodies (Pincus, Schur, Rose, Decker, and Talal, 1969; Hughes, Cohen, and Christian, 1971). However, this assay has certain inherent problems in the separation of bound from free antigen which led us to examine the use of immunoprecipitation with an anti-human gamma globulin. This communication describes a method using a double or second antibody.

\section{Material and methods}

(1) EXTRACTION OF LABELLED DNA

Thymidine-2- ${ }^{14} \mathrm{C}$ or thymidine- $6-{ }^{3} \mathrm{H}$ (Amersham) was incubated with 20 to $30 \times 10^{6}$ HeLA cells cultured in Eagle's MEM for 72 hrs. After the supernatant had been poured off the monolayers were trypsinized $(0.25$ per cent. bovine pancreatic trypsin in Hanks's basic salt solution), the cells washed twice in Earle's saline, and the DNA extracted by using a modification of the method of Marmur (1961). The cells were disrupted by 1 per cent. sodium lauryl sulphate in $1 \mathrm{M}$ sodium perchlorate. The resulting viscous solution was washed five times with chloroform saturated with water (containing 1 per cent. isoamylalcohol) until the white protein precipitate was no longer visible at the interface. The DNA in the final aqueous layer was precipitated with 2 volumes of ethylalcohol, 'spooled' into citrate saline buffer $(0.15 \mathrm{~m} \mathrm{NaCl}$ in $0.015 \mathrm{~m}$ sodium citrate (SCS) pH 7·1), and allowed to dissolve. Before the DNA was used it was purified further by two chloroform washes and reprecipitated with 2 volumes of ethylalcohol overnight at $-20^{\circ} \mathrm{C}$. After centrifugation at $2,000 \mathrm{G}$ for $30 \mathrm{~min}$., the DNA was re-dissolved again in citrate saline buffer and stored at $-20^{\circ} \mathrm{C}$. The specific activity of the ${ }^{14} \mathrm{C}$ or ${ }^{3} \mathrm{H}$ labelled product ranged from 0.005 to $0.14 \mu \mathrm{c}$. $/ \mu \mathrm{g}$. and was used in the method described. DNA labelled with a gamma emitter could also be obtained by incubation of the thymidine analogue 5-iododeoxyuridine ${ }^{125} \mathrm{I}$ with HeLA cells, and provided a satisfactory alternative.

\section{(2) ASSAY FOR DNA ANTIBODIES}

$50 \mu$ l. serum was diluted 10 -fold with $0.15 \mathrm{M}$ borate saline buffer $\mathrm{pH} 7 \cdot 8$ and heated at $56^{\circ} \mathrm{C}$. for $30 \mathrm{~min}$. Duplicate $50-\mu \mathrm{l}$. aliquots were then incubated with an equal volume of SCS buffer containing labelled DNA equivalent to $1 \mu \mathrm{g}$. as estimated by optical density readings at $260 \mathrm{~m} \mu$. The mixture was incubated for $1 \mathrm{hr}$ at $37^{\circ} \mathrm{C}$. and $16 \mathrm{hrs}$ at $4^{\circ} \mathrm{C}$. The bound antigen was then separated from free antigen by one of two following methods:

\section{(a) Double antibody}

$100 \mu$ l. of a goat anti-human gamma globulin* diluted in borate saline buffer and used in excess was added to each tube and incubated at $4^{\circ} \mathrm{C}$. The best time course for the double antibody method was determined by experiments in which the bound DNA was separated at intervals over 0 to 96 hrs (Figure, opposite).

Thereafter a 24-hr separation was used routinely. After centrifugation at $2,000 \mathrm{G} \times 1 \mathrm{hr}$ at $4^{\circ} \mathrm{C}$. the supernatant was usually discarded and the precipitate dissolved in $400 \mu \mathrm{l}$. distilled water and counted in Bray's scintillant. $\dagger$ A range of antisera used as the second antibody included those specific for the heavy chains of IgG, IgM, and IgA, to determine the class of DNA antibody.

\section{(b) Ammonium sulphate}

$100 \mu \mathrm{l}$. of a saturated solution of ammonium sulphate was added to each tube to give a 50 per cent. saturated mixture which after incubation at $4^{\circ} \mathrm{C}$. for $1 \mathrm{hr}$ was centrifuged at $2,000 \mathrm{G} \times 1 \mathrm{hr}$ at $4^{\circ} \mathrm{C}$. Half of the

* Antibodies Inc. Box 1482 Davis, California 95616. $\dagger$ Bray's scintillant (1960). 


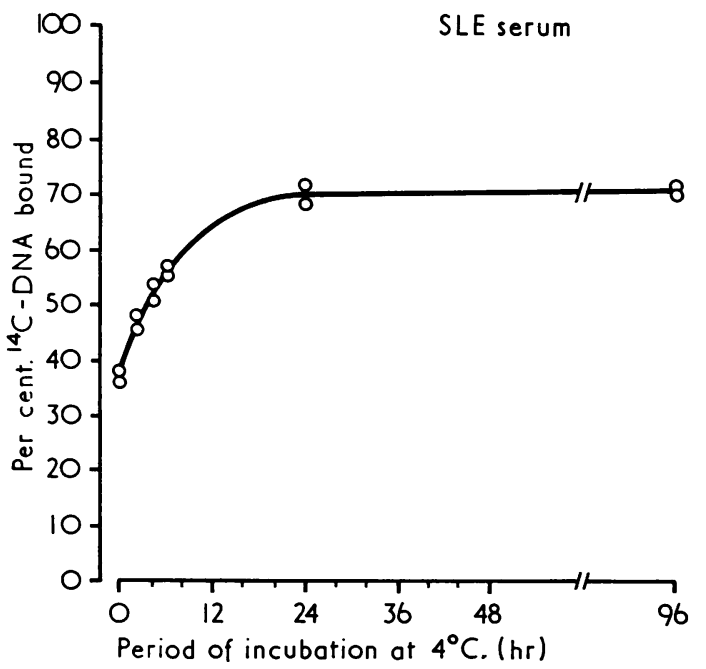

FIGURE Time course for addition of second antibody

supernatant (i.e. $100 \mu \mathrm{l}$.) was removed and the remainder was dissolved in water and both fractions counted in parallel using Bray's scintillant.

\section{(3) CRITERIA FOR SERUM SAMPLE SELECTION}

To estimate the precision of each method, 125 sera from normal individuals and 125 sera from SLE patients were assayed by both methods, each in duplicate pairs. The results were arbitrarily grouped into the following four ranges of percentage DNA binding: 0-25, 25-50, 50-75, and 75-100. Each group contained at least twenty duplicate pairs measured by both assays.

\section{(4) EXTRACTION OF DNA ANTIBODY FROM RENAL TISSUE}

DNA antibody was extracted in glycine buffer at pH 2.4 from a homogenate of a kidney obtained at autopsy of a patient with lupus nephritis, using the method described by Koffler, Schur, and Kunkel (1967). The eluate, supplemented with 10 per cent. normal human serum, was examined for the relative concentrations of immunoglobulin classes of DNA antibody in the manner described above for sera, by addition of monospecific antisera to IgG, IgM, and IgA.

\section{(5) CALCULATION AND STATISTICAL SIGNIFICANCE OF RESULTS}

The percentage DNA bound was calculated for the ammonium sulphate method of separation by using supernatant and precipitate counts. and for the double antibody assay by counting the precipitate only.
For ammonium sulphate,

$$
\text { Percentage DNA bound }=\frac{R-S u}{R+S u} \times 100,
$$

where $\mathbf{S u}=$ disintegrations per min. (d.p.m.) in half the supernatant and $R=$ d.p.m. in the remaining supernatant and the precipitate.

For the double antibody assay,

Percentage DNA bound =

$$
\frac{\text { d.p.m. in precipitate }}{\text { d.p.m. of total DNA }} \times 100 \text {. }
$$

Precision of the results within the five groups for each assay was calculated by the formula derived by Snedecor (1952) for assessing differences between duplicates where $\mathbf{S}$ (the standard deviation) is calculated as follows:

$$
S=\sqrt{\frac{d^{2}}{2 N}}
$$

where $d=$ difference between any two duplicates and $\mathbf{N}=$ number of duplicates.

The fiducial limits were obtained using Fisher's formula:

$$
\text { Fiducial range }=M \pm \frac{t S}{\sqrt{\mathbf{N}}},
$$

where $M$ is any value of per cent. DNA binding; $t$ is the appropriate Student's factor obtained from tables of probability; $\mathrm{N}$ is the number of replicate values; and $\mathrm{S}$ is the standard deviation.

\section{Results}

The double antibody and ammonium sulphate separations gave comparable mean values for each of the four ranges of the lupus and 25 normal sera tested (see Table I). The coefficient of correlation between the two methods was $r=0.91(\mathrm{P}<0.001)$.

Table II shows duplicate values of DNA binding in twenty separate samples in the 0 to 25 per cent. range. The double antibody values were in general closer to one another than those obtained with ammonium sulphate. When the differences between the dupli-

\begin{tabular}{|c|c|c|c|}
\hline \multicolumn{2}{|c|}{ Percentage DNA binding } & $\begin{array}{l}\text { Ammonium } \\
\text { sulphate }\end{array}$ & $\begin{array}{l}\text { Double } \\
\text { antibody }\end{array}$ \\
\hline \multicolumn{2}{|c|}{ Healthy controls* } & 2 & 6 \\
\hline $\begin{array}{l}\text { SLE† } \\
\text { sera [range] }\end{array}$ & $\begin{array}{c}0-25 \\
25-50 \\
50-75 \\
75-100\end{array}$ & $\begin{array}{r}8 \\
33 \\
63 \\
78\end{array}$ & $\begin{array}{r}99 \\
38 \\
57 \\
87\end{array}$ \\
\hline
\end{tabular}
cates were evaluated, the 95 per cent. fiducial limits

Table I Mean values of DNA binding of normal and SLE sera

* 25 sera.

+100 sera. 
Table II Duplicate DNA-binding percentages estimated by double antibody and ammonium sulphate separation $S L E$ sera: 0 to 25 per cent. range

\begin{tabular}{|c|c|c|c|c|c|c|c|c|c|c|c|c|c|c|c|c|c|c|c|c|}
\hline \multirow{2}{*}{ 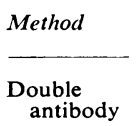 } & \multicolumn{20}{|c|}{ DNA-binding (duplicate percentages) } \\
\hline & $\begin{array}{l}2 \cdot 1 \\
2 \cdot 3\end{array}$ & $\begin{array}{l}3 \cdot 4 \\
5 \cdot 1\end{array}$ & $\begin{array}{l}4 \cdot 0 \\
5 \cdot 3\end{array}$ & $\begin{array}{l}4 \cdot 4 \\
5 \cdot 0\end{array}$ & $\begin{array}{l}4 \cdot 6 \\
4 \cdot 8\end{array}$ & $\begin{array}{l}4 \cdot 8 \\
4 \cdot 8\end{array}$ & $\begin{array}{l}5 \cdot 0 \\
5 \cdot 9\end{array}$ & $\begin{array}{l}5 \cdot 3 \\
6 \cdot 1\end{array}$ & $\begin{array}{l}5 \cdot 5 \\
6 \cdot 6\end{array}$ & $\begin{array}{l}5 \cdot 6 \\
7 \cdot 8\end{array}$ & $\begin{array}{l}5 \cdot 7 \\
6 \cdot 4\end{array}$ & $\begin{array}{l}6 \cdot 3 \\
7 \cdot 7\end{array}$ & $\begin{array}{l}7 \cdot 7 \\
8 \cdot 3\end{array}$ & $\begin{array}{l}8 \cdot 3 \\
9 \cdot 8\end{array}$ & $\begin{array}{r}9 \cdot 9 \\
10 \cdot 7\end{array}$ & $\begin{array}{l}12 \cdot 4 \\
12 \cdot 5\end{array}$ & $\begin{array}{l}15 \cdot 3 \\
15 \cdot 6\end{array}$ & $\begin{array}{l}15 \cdot 3 \\
16 \cdot 5\end{array}$ & $\begin{array}{l}15 \cdot 6 \\
17 \cdot 2\end{array}$ & $\begin{array}{l}21 \cdot 9 \\
25 \cdot 1\end{array}$ \\
\hline $\begin{array}{c}\text { Ammonium } \\
\text { sulphate }\end{array}$ & $\begin{array}{l}6 \cdot 0 \\
6 \cdot 8\end{array}$ & $\begin{array}{r}-1.5 \\
0.0\end{array}$ & $\begin{array}{l}3 \cdot 2 \\
5 \cdot 5\end{array}$ & $\begin{array}{r}-2 \cdot 1 \\
4 \cdot 9\end{array}$ & $\begin{array}{r}8 \cdot 3 \\
10 \cdot 8\end{array}$ & $\begin{array}{l}10 \cdot 8 \\
16 \cdot 2\end{array}$ & $\begin{array}{l}1 \cdot 9 \\
3 \cdot 6\end{array}$ & $\begin{array}{r}-1 \cdot 5 \\
2 \cdot 1\end{array}$ & $\begin{array}{r}1 \cdot 3 \\
-3 \cdot 4\end{array}$ & $\begin{array}{r}4 \cdot 5 \\
10 \cdot 1\end{array}$ & $\begin{array}{l}19 \cdot 4 \\
22 \cdot 9\end{array}$ & $\begin{array}{l}0 \cdot 0 \\
3 \cdot 8\end{array}$ & $\begin{array}{l}10 \cdot 1 \\
11 \cdot 3\end{array}$ & $\begin{array}{l}1 \cdot 1 \\
4 \cdot 6\end{array}$ & $\begin{array}{l}0 \cdot 0 \\
0 \cdot 0\end{array}$ & $\begin{array}{l}-2 \cdot 6 \\
-4 \cdot 7\end{array}$ & $\begin{array}{l}11 \cdot 1 \\
21 \cdot 6\end{array}$ & $\begin{array}{l}12 \cdot 2 \\
13 \cdot 7\end{array}$ & $\begin{array}{l}11 \cdot 5 \\
14 \cdot 5\end{array}$ & $\begin{array}{l}13 \cdot 6 \\
27 \cdot 6\end{array}$ \\
\hline
\end{tabular}

obtained for both are as shown in Table III. It can be seen that, for any estimate of DNA binding, the double antibody separation gives a more precise value than the ammonium sulphate separation. For example, a serum giving a 60 per cent. binding value would fall between 53.9 and $66 \cdot 1$ per cent. for the double antibody separation and between 47.6 and 72.4 per cent. for the ammonium sulphate separation on 95 out of 100 occasions.

Table III Comparison of 95 per cent. fiducial limits using double antibody or ammonium sulphate separations

\begin{tabular}{|c|c|c|c|}
\hline \multicolumn{2}{|c|}{ Method of separation } & $\begin{array}{l}\text { Double } \\
\text { antibody }\end{array}$ & $\begin{array}{l}\text { Ammonium } \\
\text { sulphate }\end{array}$ \\
\hline \multicolumn{2}{|c|}{ Healthy controls } & $\mathbf{M} \pm 3 \cdot 1$ & $M \pm 6.6$ \\
\hline $\begin{array}{l}\text { SLE sera } \\
\text { range } \\
\text { (per cent.) }\end{array}$ & $\begin{array}{c}0-25 \\
25-50 \\
50-75 \\
75-100\end{array}$ & $\begin{array}{l}M \pm 2 \cdot 6 \\
M \pm 5 \cdot 3 \\
M \pm 6 \cdot 1 \\
M \pm 6 \cdot 7\end{array}$ & $\begin{array}{l}M \pm 6 \cdot 3 \\
M \pm 8 \cdot 4 \\
M \pm 12 \\
M \pm 15\end{array}$ \\
\hline
\end{tabular}

$M=$ Any DNA-binding value within the stated ranges.

The relative DNA binding of the immunoglobulin classes can be detected readily. In the example in Table IV, the patient's serum values are compared with the values obtained with DNA antibodies extracted from her kidney obtained post mortem.

Table IV Immunoglobulin in classes of DNA antibodies present in serum and renal tissue of a patient with SLE (per cent. DNA binding)

\begin{tabular}{lll}
\hline $\begin{array}{lll}\text { Double antibody } \\
\text { specificity }\end{array}$ & Serum & $\begin{array}{l}\text { Post mortem renal tissue } \\
\text { eluate } p H 2 \cdot 4\end{array}$ \\
\cline { 1 - 2 } Anti IgG & -31 & 94 \\
Anti IgM & $18 \cdot 5$ & 13 \\
Anti IgA & $25 \cdot 5$ & 4 \\
\hline
\end{tabular}

\section{Discussion}

In our experience the double antibody assay of DNA binding in serum gives a method which has narrower confidence limits than the ammonium sulphate assay. It is at the same time technically simpler for routine use because the precipitate is easy to separate by simply tipping off the supernatant in contrast to the friable and less stable precipitate obtained with ammonium sulphate which has to be carefully separated from the supernatant. Moreover, the values from counting the precipitate alone were comparable to those obtained by counting both the precipitate and supernatant thus simplifying the procedure further.

The improved precision of the double antibody method gives a more sensitive assay which allows better discrimination between lupus and normal sera. Furthermore, the change in a given value of binding at any range that will be significant will be smaller allowing more meaningful comparisons.

Numerous other methods of separating bound from free antigens are available (Hunter and Ganguli, 1971), and DNA antibody has been assayed by the use of a membrane filter separation (Ginsberg and Keiser, 1972) and a solid phase separation (Epstein, Tan, and Easterbrook, 1971). The double antibody separation has been compared with the ammonium sulphate method in terms of its biological specificity for antibodies to bovine serum albumin and gave corresponding results (Minden, Anthony, and Farr, 1969). In this study a good correlation has also been demonstrated between the two methods. The further advantage of the double antibody assay lies in being able to define the class of DNA antibody by using monospecific antisera and the heterogeneity of DNA antibodies is illustrated in $N$ Table IV. Inspection of the Table shows that, whereas $N$ in this instance (from a patient with SLE dying of renal failure) the three classes are distributed roughly equally in the serum, renal tissue contained predominantly IgG DNA antibody. Such data derived from the use of this easily-performed double antibody assay are currently being extended and evaluated to assess their full clinical significance.

We are grateful to Miss L. Roffe and Mr. P. Hill for their assistance; to Dr. Graham Hughes and Dr. Hugh Harley for helpful discussion; and to the Clinical Research Committee of Charing Cross Hospital and the Arthritis and 8 Rheumatism Council for their support. 


\section{References}

BrAY, G. A. (1960) Analyt. Biochem., 1, 279 (A simple efficient liquid scintillator for counting aqueous solutions in a liquid scintillation counter)

Ceppellini, R., Polli, E., ANd Celada, F. (1957) Proc. Soc. exp. Biol. (N.Y.), 96, 572 (A DNA-reacting factor in serum of a patient with lupus erythematosus diffusus)

Epstein, W. V., TAN, M., AND EASTERBroOK, M. (1971) New Engl.J. Med., 285, 1502 (Serum antibody to doublestranded RNA and DNA in patients with idiopathic and secondary uveitis)

GinsBerg, B., AND KeISER, H. (1972) Arthr. and Rheum. 15, 438 (Assay of antibodies to double-stranded DNA by millipore filter)

Hughes, G. R. V., Cohen, S. A., And Christian, C. L. (1971) Ann. rheum. Dis., 30, 259 (Anti-DNA activity in systemic lupus erythematosus: a diagnostic and therapeutic guide)

HUNTER, W., AND GANGULI, P. C. (1971) 'The separation of antibody' in 'Radioimmunoassay Methods', ed. K. Kirkham and W. M. Hunter, p. 243. Churchill Livingstone, London

KoffLer, D., SCHUR, P. H., AND KUNKeL, H. G. (1967) J. exp. Med., 126, 607 (Immunological studies concerning the nephritis of systemic lupus erythematosus)

MARMUR, J. (1961) J. molec. Biol., 3, 208 (A procedure for the isolation of deoxyribonucleic acid from micro-organisms)

Minden, P., ANTHONY, B. F., AND FARR, R. S. (1969) J. Immunol., 102, 832 (A comparison of seven procedures to detect the primary binding of antigen by antibody)

Pincus, T., Schur, P. H., Rose, J. A., Decker, J. L., AND Talal, N. (1969) New Engl.J. Med., 281, 701 (Measurement of serum DNA binding activity in systemic lupus erythematosus)

Seligmann, M. (1957) C. R. Acad. Sci. (Paris), 245, 243 (Sérologie-mise en évidence dan le sérum des malades atteints de lupus érythémateux disséminé d'une substance déterminant une réaction de précipitation avec l'acide désoxyribonucléique)

SNedeCOR, G. W. (1952) Biometrics, 8, 85

TAN, E. M., Schur, P. H., CARr, R. I., AND Kunkel, H. G. (1966) J. clin. Invest., 45, 1732 (Deoxyribonucleic acid (DNA) and antibodies to DNA in the serum of patients with systemic lupus erythematosus)

Wold, R. T., Young, F. E., TAN, E. M., AND FARR, R. S. (1968) Science, 161, 806 (Deoxyribonucleic acid antibody: a method to detect its primary interaction with deoxyribonucleic acid) 